\title{
Tau, prions and Aß: the triad of neurodegeneration
}

\author{
Lilla Reiniger • Ana Lukic $\cdot$ Jacqueline Linehan • \\ Peter Rudge $\cdot$ John Collinge $\cdot$ Simon Mead • \\ Sebastian Brandner
}

Received: 30 March 2010/Revised: 25 April 2010/Accepted: 26 April 2010/Published online: 16 May 2010

(C) The Author(s) 2010. This article is published with open access at Springerlink.com

\begin{abstract}
This article highlights the features that connect prion diseases with other cerebral amyloidoses and how these relate to neurodegeneration, with focus on tau phosphorylation. It also discusses similarities between prion disease and Alzheimer's disease: mechanisms of amyloid formation, neurotoxicity, pathways involved in triggering tau phosphorylation, links to cell cycle pathways and neuronal apoptosis. We review previous evidence of prion diseases triggering hyperphosphorylation of tau, and complement these findings with cases from our collection of genetic, sporadic and transmitted forms of prion diseases. This includes the novel finding that tau phosphorylation consistently occurs in sporadic CJD, in the absence of amyloid plaques.
\end{abstract}

\section{Cerebral amyloid, tau phosphorylation and cell death: how are they connected?}

Human prion diseases represent a clinically and pathologically diverse group of neurodegenerative disorders

Electronic supplementary material The online version of this article (doi:10.1007/s00401-010-0691-0) contains supplementary material, which is available to authorized users.

L. Reiniger $\cdot$ S. Brandner $(\bowtie)$

Division of Neuropathology, Department of Neurodegenerative Disease, UCL Institute of Neurology, Queen Square,

WC1N 3BG London, UK

e-mail: s.brandner@ion.ucl.ac.uk

A. Lukic $\cdot$ P. Rudge $\cdot$ J. Collinge $\cdot$ S. Mead

National Prion Clinic, UCL Institute of Neurology and National

Hospital for Neurology and Neurosurgery, London, UK

J. Linehan $\cdot$ J. Collinge $\cdot$ S. Mead

MRC Prion Unit and Department of Neurodegenerative Disease,

UCL Institute of Neurology, London, UK including (1) sporadic Creutzfeldt-Jakob disease (sCJD), (2) inherited forms of prion diseases (inherited prion disease, IPD) such as Gerstmann-Sträussler-Scheinker syndrome (GSS) or fatal familial insomnia (FFI) and (3) acquired forms, such as variant CJD (vCJD), iatrogenic CJD (iCJD) and Kuru. We avoid the term "familial CJD", as CJD was originally defined as a clinicopathological syndrome which is distinct from e.g. GSS or FFI. The term IPD links the different syndromes by pathogenesis and is therefore preferred.

According to the protein-only hypothesis [40], infectious prions are composed predominantly, if not entirely, of aggregates of misfolded, host-encoded, cellular prion protein $\left(\mathrm{PrP}^{\mathrm{C}}\right)$, commonly designated $\operatorname{PrP}^{\mathrm{Sc}}[83]$. $\operatorname{PrP}^{\mathrm{Sc}}$ arises from normal prion protein $\left(\operatorname{PrP}^{\mathrm{C}}\right)$ through conformational conversion. The common neuropathological feature of prion diseases is a predominantly extracellular accumulation of $\operatorname{PrP}^{\mathrm{Sc}}$ in the central nervous system. Prion protein deposits are highly variable in their intensity (Fig. 1; Table 1), pattern, i.e. plaques (Fig. 1m-o), perineuronal labelling (Fig. 1p-r), synaptic deposition (Fig. 1j-l) and formation of coarse granular deposits (Fig. 1g-i) and their distribution within the CNS. These deposits correspond biochemically to amyloid, i.e. aggregates of protein with high content of $\beta$-sheets. The deposits are accompanied by spongiform change with neuronal vacuolation and degeneration (Fig. 1a-f) and astrocytic and microglial reaction, all of which can vary considerably within the CNS and between different individuals.

Whilst prion diseases can be readily transmitted via various routes and between species, the most common $A \beta$ amyloidosis is transmissible at a considerably lower efficiency, and has to date been limited to experimental settings [29]. Another well recognised CNS amyloidosis, familial British dementia (FBD) has not been experimentally tested for transmissibility. 
Fig. 1 Spongiform changes and PrP deposition in sporadic prion disease: severity of spongiform changes, ranging from mild to moderate and severe, with diffuse, homogenous spongiform changes $(\mathbf{a}-\mathbf{c})$ and patchy confluent vacuolisation (d-f). Patterns and intensities of commonly observed prion protein deposits: $\mathbf{g}$-i coarse granular deposits of prion protein, which may form confluent aggregates. $\mathbf{j}-\mathbf{l}$ Synaptic PrP, ranging from mild to severe, and $\mathbf{m}-\mathbf{0}$, formation of plaques in sporadic CJD. All patterns and intensities are used in the scoring scheme to compare with tau burden in our series; $160 \mu \mathrm{m}(\mathbf{a}-\mathbf{c}, \mathbf{m}-\mathbf{o})$, $300 \mu \mathrm{m}(\mathbf{d}-\mathbf{f}, \mathbf{p}-\mathbf{r}), 80 \mu \mathrm{m}(\mathbf{j}-\mathbf{l})$

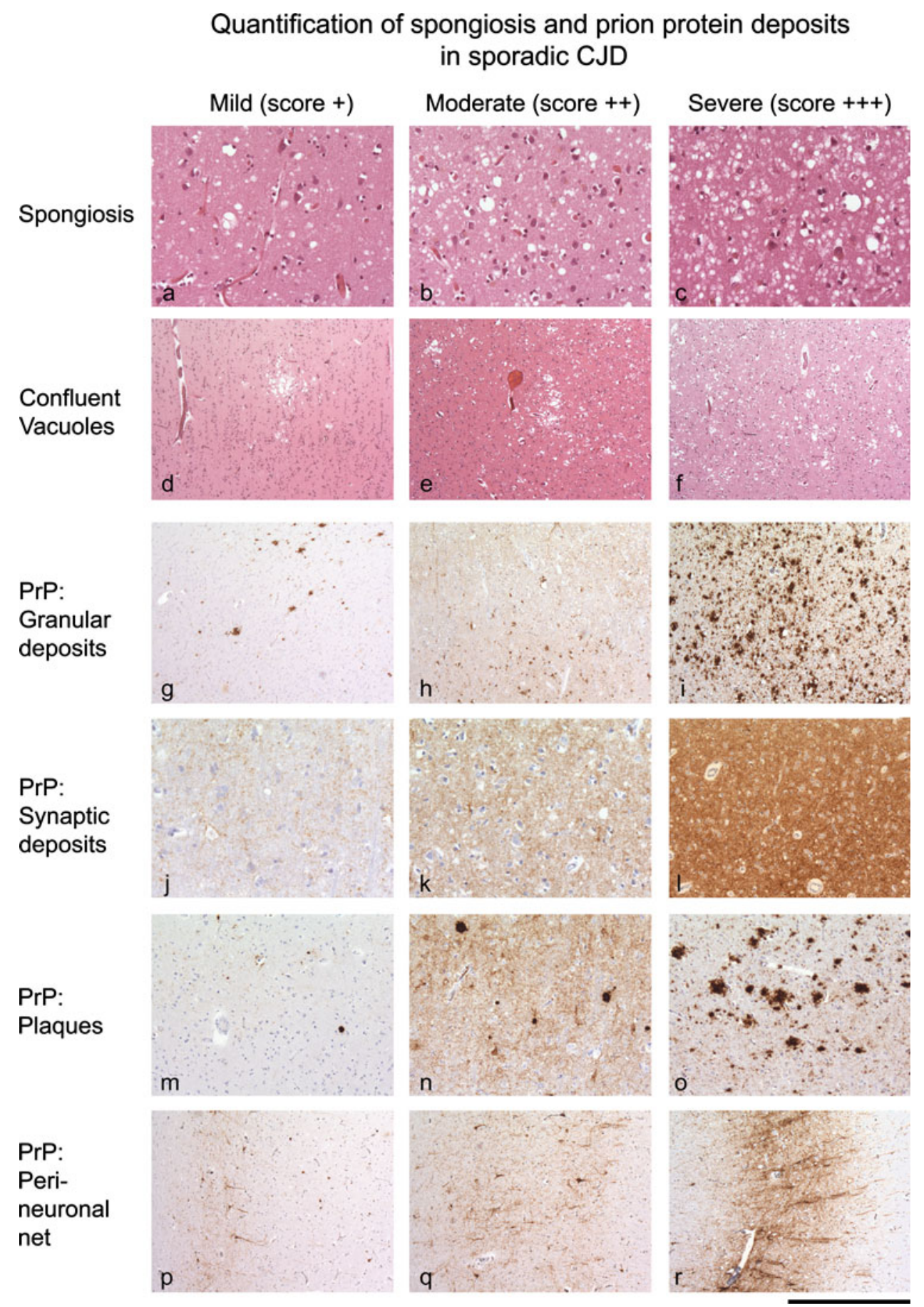

In the last few years, a striking number of epidemiological, neuropathological, and biochemical similarities between prion diseases and Alzheimer's disease have been identified, in particular the fact that there are interactions between the two proteins [41, 59, 74] and between the signalling pathways involving both proteins.

Epidemiologically and clinically, both disorders are dementing illnesses that mainly occur sporadically, but can also occur as familial forms. Histopathologically, both are characterised by the deposition of an extracellular amyloid that is produced by neurones. In both diseases, there is formation of amyloid oligomers and ultimately also of solid amyloid aggregates in the brain (Figs. 1g-o, 2a-f; Table 1): both amyloid proteins can accumulate diffusely (Fig. 2a-c), or they can exhibit prominent and widespread deposition of dense amyloid plaques with a diameter of more than $200 \mu \mathrm{m}$ (Fig. 2d-f), and both elicit a considerable astrocyte and microglial reaction, variable neuronal 


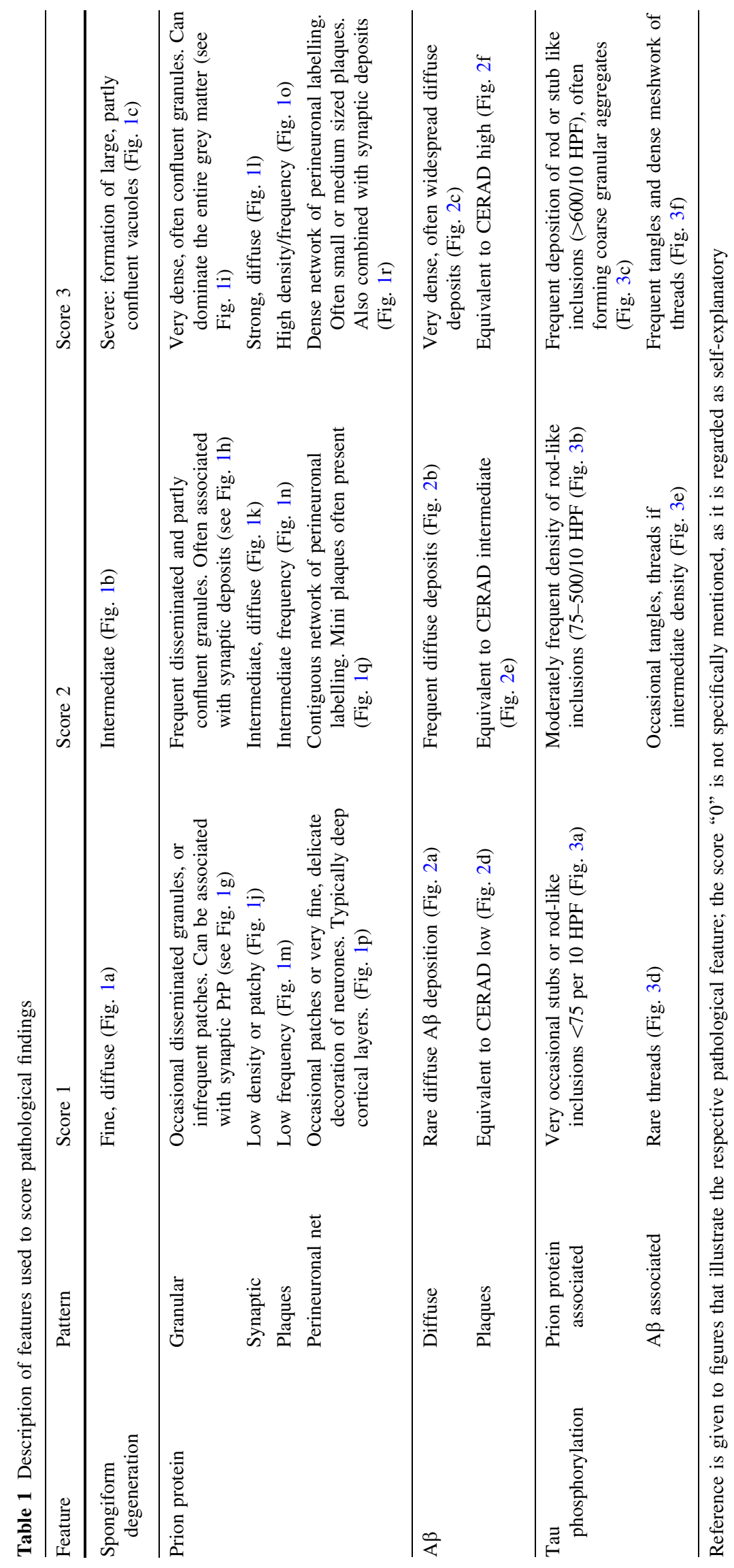




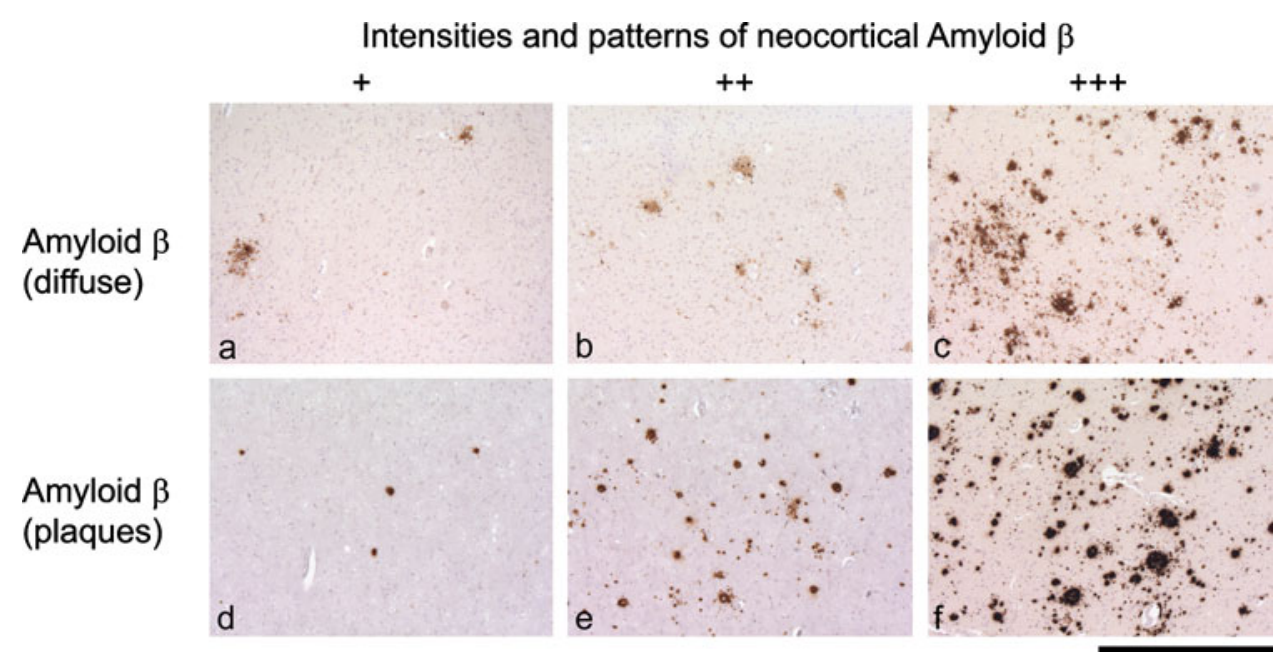

Fig. 2 Intensities of $A \beta$ deposits: $\mathbf{a}-\mathbf{c}$ diffuse protein deposits without formation of plaques (ranging from mild to severe). a Score 1 (mild) describes occasional patchy deposits, occasionally seen on low power magnification. b Moderate, score 2 describes deposits that are seen in $<50 \%$ of adjacent low power fields. c An example of

loss, and occasionally deposition of amyloid in or around vessels walls.

Biochemically, both diseases are characterised by aggregation of a protein that is encoded and expressed by the host. It was recently suggested that $A \beta 42$ may act through a PrP receptor $[41,59]$. Experimental data suggest that there is a functional link between $\operatorname{PrP}^{\mathrm{C}}$ and $\mathrm{A} \beta$ processing: (1) knockdown of $\operatorname{PrP}^{C}$ in N2A cells increases $A \beta$ levels in vitro, (2) PrP knockout mice as well as scrapieinfected mice show increased $A \beta$ level and (3) $\operatorname{PrP}^{C}$ overexpression reduces $A \beta$ formation by downregulating the APP cleaving enzyme $\beta$-secretase [77].

Recent genetic evidence also links prion disease to Alzheimer's disease, in that the APOE-E4 allele, a wellestablished risk factor for $\mathrm{AD}$, also may increase the risk for sporadic CJD [57], but surprisingly may delay onset of inherited prion disease with the P102L mutation [92]. A detailed discussion of the similarities between CJD and $\mathrm{AD}$, the relationship between codon 129 polymorphism and a model of $\mathrm{A} \beta 42$ action through $\mathrm{PrP}^{\mathrm{C}}$ receptor are given in a review by Gunther and Strittmatter [41].

\section{The amyloid cascade hypothesis}

According to the amyloid cascade hypothesis, proposed by Hardy and Higgins [44] the increased production or decreased clearance of amyloid beta $(A \beta)$ peptides results in the accumulation of the hydrophobic $A \beta 40$ and $A \beta 42$ peptides with subsequent aggregation and formation of insoluble plaques. This induces a cascade of deleterious changes, such as neuronal death and eventually causes Alzheimer's heavier diffuse amyloid beta burden, indicating a presence in most of the low power field on a cortex section. Dense core amyloid beta plaques, approximately corresponding to CERAD sparse (d), intermediate (e) and high (f). Scale bar $300 \mu \mathrm{m}(\mathbf{a}-\mathbf{f}, \mathbf{g}-\mathbf{i})$

disease. Since then, this hypothesis underwent several transformations due to the accumulating data supportive of or inconsistent with the theory [81]. The current version assumes a toxic role of soluble prefibrillar oligomers based on the several in vivo and in vitro experiments [37, 42]. The results contradicting these findings $[61,86,90]$ and the recognised experimental artifacts [7] make it more difficult to elucidate their genuine role in disease development. However, a number of recent studies in transgenic mice have further strengthened the concept of the amyloid cascade hypothesis: intracerebral injection of $A \beta$ seeds trigger the aggregation of endogenous $A \beta$ : intracerebral inoculation of APP23 transgenic mice with brain homogenates from Alzheimer's patients or with brain extracts from aged APP23 transgenic mice elicits a marked anticipation of the disease in young APP23 mice [69]. This finding can be interpreted as prion-like transmission or as seeding process. The latter is a more likely scenario, as implantation of small steel wires coated with minute amounts of $A \beta$-containing brain homogenate into the brain of APP23 transgenic mice triggered significant deposition of $A \beta$ in the CNS, whilst peripheral inoculation of these mice with $A \beta$ did not seed in the CNS [29]. It may be argued that the presence of a prion receptor, but not of an "A $\beta$ " receptor in peripheral tissues, such as nerve endings or immune cells.

\section{Cerebral amyloid and tau hyperphosphorylation: what is the trigger?}

A prominent feature of cerebral amyloidoses is the induction of tau hyperphosphorylation. This is very well 


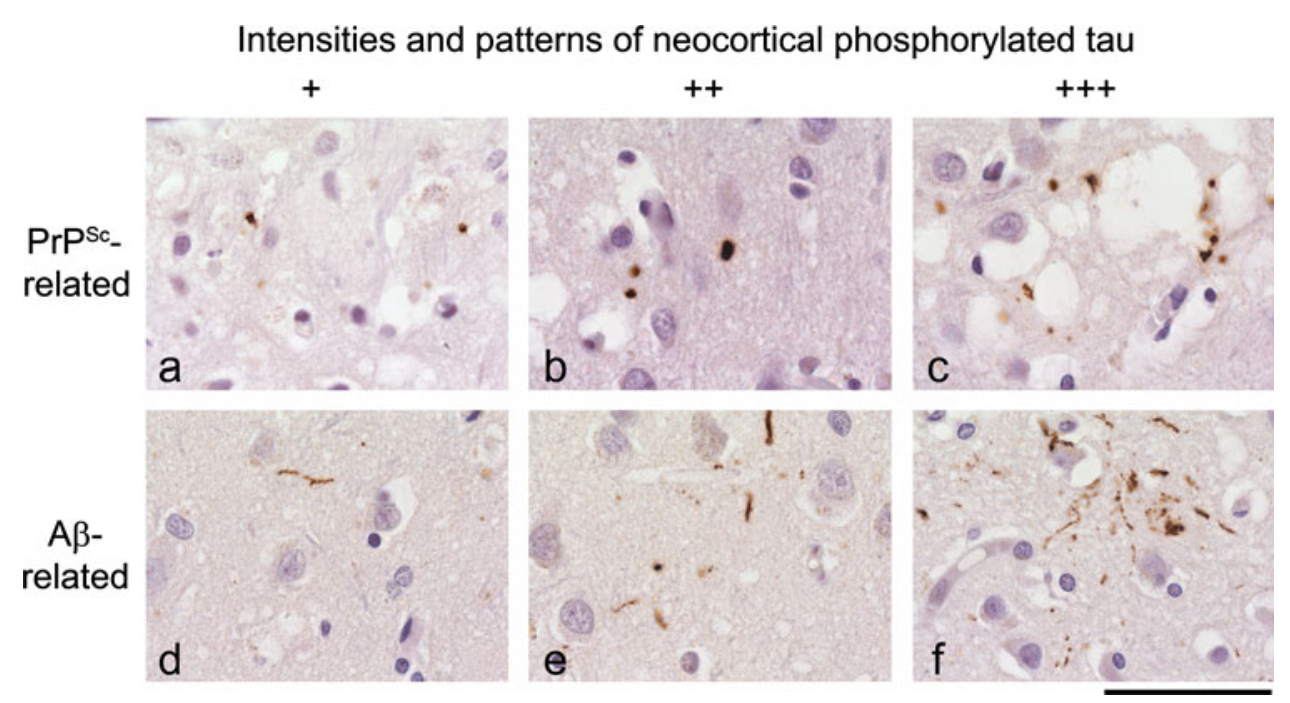

Fig. 3 Amyloid beta or PrP induced pattern of tau phosphorylation differ: a-c the range of PrP induced tau deposits. The scores of tau correspond to the scores of PrP shown in Fig. 1, i.e. tau score 1 is typically seen in areas with PrP score 1 and dense tau deposits (scores 2 or 3 ) is typically seen in areas with PrP scores $2-3$. d-f In contrast,

established for Alzheimer's disease (AD), but is also a prominent feature in the rare FBD and has been sporadically described for prion diseases mostly in the context of the presence of plaques, such as in VCJD or in many inherited forms. A prominent feature of $\mathrm{AD}$ is the accumulation of hyperphosphorylated tau within or in the vicinity of cortical amyloid deposits (Fig. 3d-f). Importantly, this direct association of tau pathology in areas of $\mathrm{A} \beta$ accumulation has to be separated from a probably independent process of tau phosphorylation that starts in the entorhinal cortex and spreads over the limbic system and finally extends into neocortical regions. This latter process has been characterised in detail and was formalised in a staging system developed and defined by Braak and Braak $[10,11]$. The clinical dementia correlates better with the Braak stage than with the deposition of $A \beta$.

FBD is an autosomal dominant, neurodegenerative disorder, presenting with dementia, spastic tetraparesis, and cerebellar ataxia, also known as Worster-Drought syndrome [68, 82, 85, 94]. Similar to Alzheimer's disease, in particular its inherited forms, the neuropathological hallmarks of FBD include extensive cerebral amyloid angiopathy (CAA), cerebellar degeneration with severe CAA and parenchymal amyloid plaques. There are also hippocampal amyloid plaques as well as neurofibrillary tangles, and white matter degeneration similar to that seen in Binswanger's disease [50]. Deposition of hyperphosphorylated tau in FBD is indistinguishable from that in AD, both immunohistochemically and ultrastructurally.

In prion disease, hyperphosphorylation of tau has been described, but it is not a well-known or well-characterised
Ab induces a threaded tau phosphorylation pattern, with elongated dystrophic neuritis but very little stub- or rod-tau. All examples are from the frontal or parietal cortex, and correspond to diffuse a beta deposits scores 1-3. Scale bar $25 \mu \mathrm{m}(\mathbf{a}-\mathbf{f})$

feature. Not much is known about the relationship between disease duration, PRNP codon 129 genotype, glycotype, histological manifestations and the degree of tau phosphorylation. Several studies have reported the deposition of hyperphosphorylated tau in small series of sporadic, familial and variant forms of prion diseases. These reports highlight the role of prion amyloid plaques as an essential prerequisite to elicit tau phosphorylation and raise important questions related to the mechanism responsible for tau phosphorylation. A detailed discussion of these reports is given below.

\section{$A \beta, \operatorname{PrP}$ and tau: their connection to cell cycle and cell death}

Several pathways are thought to play a role in neurodegenerative processes, some of which are unusual suspects. A number of cell cycle proteins have recently been implicated in neurodegenerative processes. CDK5, GSK3 $\beta$, and pAkt are all well-characterised mediators of growth, survival and inhibitors of neur(on)al differentiation. All are now also linked to the family of neurodegeneration-prion protein, $\mathrm{A} \beta$ and tau phosphorylation.

$C D K 5$, a serine-threonine kinase, is a cell cycle protein that is also responsible for processes, such as axonal guidance, cortical layering and synaptic structure/plasticity, and it is mainly expressed in postmitotic neurones [18, 78]. Dysregulation of CDK5 has been implicated in neurodegeneration for some years $[17,18,20,71,78,88]$ and it is now likely to be involved in abnormal phosphorylation 
of tau. In keeping, CDK5 inhibition alleviates tau phosphorylation and cytoskeletal lesions [96].

GSK3 $\beta$ has recently been identified as a likely candidate directly to phosphorylate tau and mechanistic links between GSK3 $\beta$, tau $[60,84]$ and $A \beta[45,46,51]$ have been established. A less well described, but mechanistically appealing connection has also been made to PrP, which makes the hypothesis of cell cycle related proteins and neurodegeneration attractive [79].

Another pathway that has been implicated in neurodegeneration involves PTEN/pAkt. The tumour suppressor PTEN antagonises the phosphorylation of Akt, hence downregulation of PTEN increases the phosphorylated, active form of Akt (pAkt), which has pro-survival, proproliferation effects and counteracts apoptosis and cell differentiation. However, whilst this function of pAkt is important and relevant for cells capable of self-renewal and proliferation, i.e. the developing CNS, it is different for quiescent/postmitotic cells, such as neurons, where constitutive activation of Akt can cause neurodegeneration [67], including abnormal phosphorylation of tau, mediated by CDK5 in a GSK3 $\beta$ independent fashion $[56,71]$. Whilst the role of $A \beta$ triggering tau phosphorylation is well established [9, 38, 62, 75], a recent study also showed that tau phosphorylation is transmissible too, which may have wide ranging implications for the concept of the involvement of $A \beta$ as the sole trigger for hyperphosphorylated tau in Alzheimer's disease [23].

Experimental evidence for the connection of tau, $A \beta$ and PrP comes from work of from Perez et al. [79]. Using PrP 106-126 peptides, a widely used paradigm to test prion toxicity in vitro, GSK3 $\beta$ mediated tau phosphorylation was induced. Other studies provide compelling evidence that CDK5, PrP and A $\beta$ are mechanistically connected and involved in neurodegeneration $[64,65]$.

\section{The PrP-tau connection (I): inherited prion diseases and phosphorylation of tau}

Inherited prion diseases display a wide spectrum of pathological deposition of prion protein. The formation of conspicuous and well-demarcated amyloid plaques is typically seen in inherited forms with codon P102L (Figs. 4m, 5c) P105L, and A117V mutations (Figs. 4n, 5d), whilst D178N or E200K (Figs. 4o, 5e) mutations show less well-defined plaque pathology. Other mutations, such as octapeptide repeat insert (OPRI) mutations present histologically with a unique striping pattern of the cerebellum (Fig. 4k, 1).

Reports of tau pathology in inherited prion diseases consistently describe marked dystrophic neurites with hyperphosphorylated tau, accentuated in the vicinity or located within amyloid plaques. The first reports were those of classical GSS with the PRNP P102L mutation [5, 8, 34, $35,73,89]$. Later studies of P102L GSS with detection of abundant phospho-tau concluded that this may be an effect of PrP-mediated phosphorylation rather than a $\mathrm{A} \beta$ related effect, as there were only minimal $A \beta$ deposits seen [52]. However, it may be argued that this latter study detected tau phosphorylation in the entorhinal cortex which has formed independently from the prion amyloid deposition, in the context of Alzheimer's disease corresponding to Braak and Braak stage I. Other mutations associated with the clinical phenotype of GSS (A117V mutation [91]), or P105L [53, 95] reported similar findings. In vitro experiments with a prion protein peptide carrying the A117V mutation decreased the rate of microtubule formation more efficiently than wild-type PrP106-126. This was thought to be related to the displacement of tau, where A $117 \mathrm{~V}$ mutation is more efficient at inhibiting microtubule formation [13].

OPRI mutations, such as 96 bp [21], or 144 bp inserts [22] into the N-terminal octarepeat region, are characterised by a unique pattern of immunoreactivity for PrP, which is oriented perpendicularly to the cerebellar surface (Fig. 4k, 1), also show a marked tau phosphorylation, which co-localises with PrP deposits. A case report of a $216 \mathrm{bp}$ OPRI mutation instead showed a pattern different from those with a shorter insert, with the formation of large amyloid plaques, again co-localising with hyperphosphorylated tau [27].

Finally, the stop mutation $145 \mathrm{X}$ [33] with formation of plaques and cerebral amyloid angiopathy ("PrP-CAA") showed similar results with tau co-localising to plaques.

\section{The PrP-tau connection (II): tau phosphorylation in sporadic and variant $\mathrm{CJD}$}

Following the observation of hyperphosphorylated tau in inherited prion diseases with remarkable tropism to amyloid plaques, but not in SCJD, several studies analysed this phenomenon further: Giaccone et al. [36] compared tau phosphorylation patterns of $\mathrm{AD}$ and $\mathrm{VCJD}$ and found the same three bands of 68, 64 and $60 \mathrm{kDa}$ in an immunoblot probed for tau. Morphologically, hyperphosphorylated tau co-localised with florid plaques. However, it was also found that unlike in $\mathrm{AD}$, there was no detectable soluble hyperphosphorylated tau in vCJD. In contrast to the findings that we report in our series (see below), their study did not detect hyperphosphorylated tau in brains of sCJD patients [36]. A study comparing the ultrastructure of prion amyloid in GSS and vCJD [87] came to a similar conclusion, but in addition found that dystrophic neurites containing hyperphosphorylated tau occurs in SCJD with small plaques. It was concluded that plaque-forming prion 


\section{Phosphorylated tau in the cerebellum (sporadic and variant CJD)}

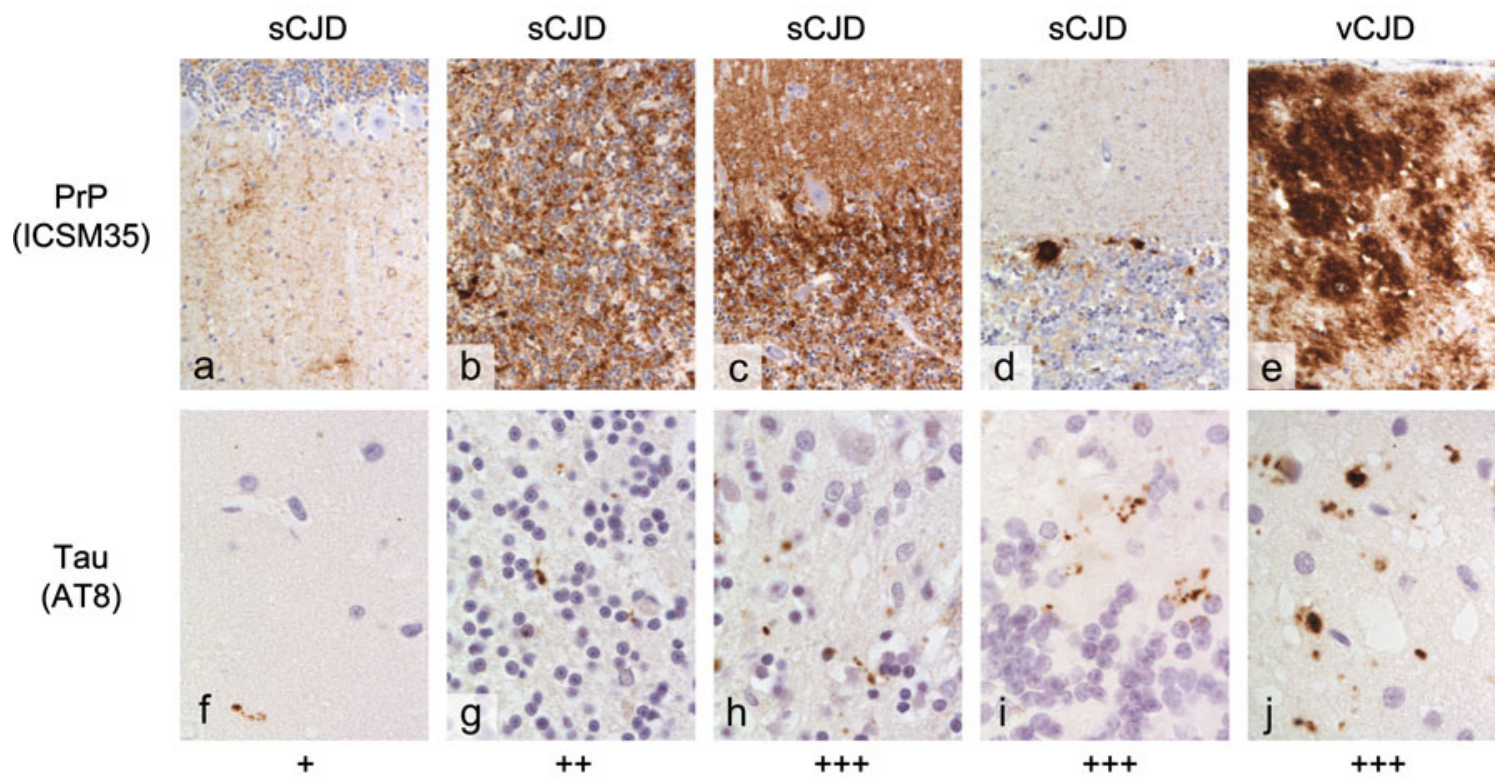

Phosphorylated tau in the cerebellum (inherited prion diseases)

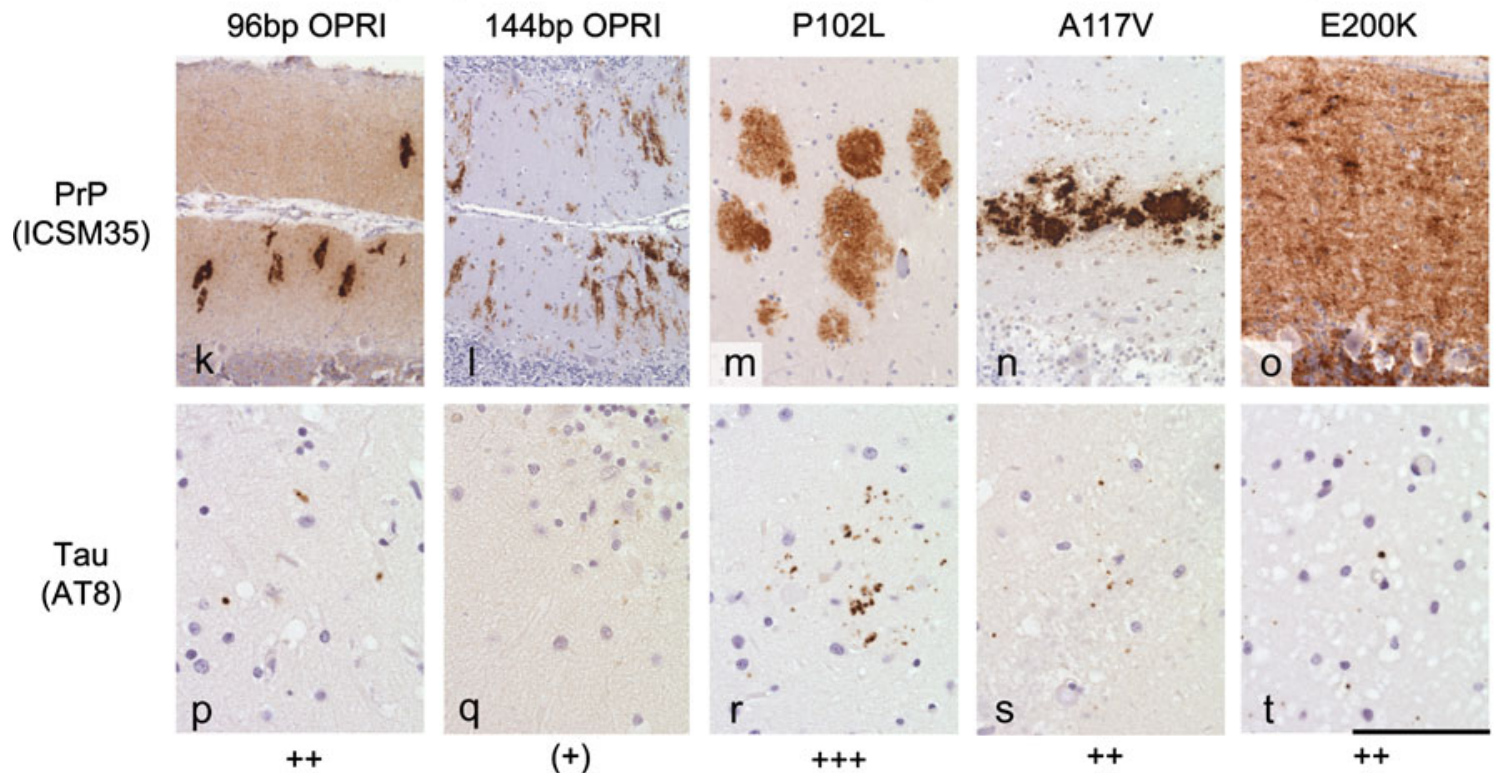

Fig. 4 Prion protein-triggered tau phosphorylation in the cerebellum: upper row deposition of abnormal PrP; sporadic CJD with synaptic PrP deposition (a-c) or with small plaques (d). e vCJD with heavy PrP burden with diffuse deposits as well as plaques. The corresponding tau phosphorylation is shown below $(\mathbf{f}-\mathbf{j})$ : it is approximately proportional to the $\mathrm{PrP}^{\mathrm{Sc}}$ burden and is also closely associated with plaques. However, an exceptionally strong tau deposit is consistently seen in vCJD cerebella (i). Inherited forms of prion disease show variable amounts of p-tau deposits, which do not correlate with the

PrP burden and also do not correlate with the pattern (plaque or synaptic): The pattern of abnormal PrP deposition is distinct for each mutation. 96 and 144 bp OPRI form a characteristic striping pattern perpendicularly to the cerebellar surface $(\mathbf{k}, \mathbf{l})$ with moderate tau labelling in the $96 \mathrm{bp}$ OPRI and very little tau in the $144 \mathrm{bp}$ OPRI. The extent of tau phosphorylation appears to be independent of the plaque load, with P102L and A117L cases showing similar tau burden as in the E200K which features synaptic PrP deposition. Scale bar $120 \mu \mathrm{m}(\mathbf{a}-\mathbf{e}, \mathbf{n}, \mathbf{o}) ; 250 \mu \mathrm{m}(\mathbf{k}, \mathbf{l}, \mathbf{m})$ and $40 \mu \mathrm{m}(\mathbf{f}-\mathbf{j}, \mathbf{p}-\mathbf{t})$

diseases are capable of generating phospho-tau deposits, but forms with synaptic PrP deposits may be incapable to do so [87].
To examine this further, we examined 79 brains from patients with sporadic CJD and compared them to 12 cases with inherited prion disease and 5 vCJD cases. We can 
demonstrate for the first time that there is indeed presence of hyperphosphorylated tau in SCJD with synaptic (Figs. $1 \mathrm{j}-1,6 \mathrm{i}, \mathrm{j}$ ) or pericellular PrP, notably also in the absence of plaques (Figs. 3a-c, 6a, b, e, f). When considering with the previous reports, we detected a very substantial formation of phospho-tau positive rods in five cases of vCJD, including two cases of blood transfusion related transmission (Fig. 4j). In those cases with concomitant A $\beta$ amyloid pathology (mild, $n=14$ ), we found both patterns, namely granular, rod-shaped PrP-induced tau inclusions (Fig. 3a-c) and thread-shaped $A \beta$ related formations (Fig. 3d-f). Cases of inherited prion disease (P102L, A117V, D178N, E200K, 96 and 144 bp octarepeat insert) show accumulation of tau directly associated with prion protein plaques (Figs. $4 \mathrm{p}-\mathrm{t}, 5 \mathrm{f}-\mathrm{j}$ ).

\section{The PrP-tau connection (III): neocortical PrP ${ }^{\mathrm{Se}}$ and pTau correlate in sporadic and in inherited forms of prion diseases}

In our series of sporadic, inherited and variant forms of prion diseases $(n=79)$, we found a correlation of prion protein burden (Fig. 1) and the formation of rod or stubshaped tau deposits in the neocortex (Fig. 3; Tables 2, 3). Previously, the ability of prion protein to hyperphosphorylate tau was thought to be associated with the presence of amyloid plaques, as seen in vCJD, GSS or certain forms of sCJD. We show here in a large cohort, that indeed synaptic PrP is directly associated with the presence of minute deposits of hyperphosphorylated tau. Regions in which prion protein deposits across the entire thickness of the cortex also show the presence of tau rods in the same area (Fig. 6i, m). Other cases where the burden of abnormal prion protein is restricted to deeper cortical layers show a distribution of tau rods congruent with prion protein accumulation and neurodegeneration (Fig. 6a, e). In sCJD, deposition of tau significantly correlates with the intensity of prion protein load (correlation coefficient $r=0.69$, $p<0.01$ ), but does not correlate with disease duration ( $r=-0.037$, n.s.). Importantly, the size of tau granules in sCJD with homogenous synaptic PrP was smaller than that in SCJD with formation of large PrP granules.

To exclude that the tau phosphorylation was induced by coexisting $A \beta$ amyloid, we stratified for presence or absence of $A \beta$ amyloid (Tables 2, 3). Almost half of the cases $(n=36)$ were entirely free of any form of $\mathrm{A} \beta$, a small number showed patchy, mild and diffuse deposits of $\mathrm{A} \beta$ (corresponding to Fig. $2 \mathrm{a})(n=13)$ and the remainder showed more intense diffuse $A \beta$ and/or core plaques (see Fig. 2b-e) $(n=27)$. The morphology of hyperphosphorylated tau associated with abnormal prion protein is remarkably distinct from that elicited by $\mathrm{A} \beta$, in particular in cases of synaptic PrP deposition (Fig. 3). Prion protein related tau hyperphosphorylation shows as short stub- or rod-like structures (Fig. $3 \mathrm{a}-\mathrm{c}$ ). The most subtle deposition forms small rod- or stub-like punctate inclusions (granules). Their shape resembles granules seen in argyrophilic grain disease [31]. They do not extend to fibrillary or "neuritic" tau, whilst the most subtle deposition of $\mathrm{A} \beta$ associated tau fibrils occurs in the form of thin, single neuritic threads in the cortex (Fig. 3d). The next stage of $\mathrm{A} \beta$-induced tau phosphorylation is a more frequent presence of fibrils (Fig. 3e), and finally the $A \beta$-induced tau pathology amounts to a delicate network of dystrophic processes (Fig. 3f), including neurofibrillary tangles. Amyloid plaques are generally surrounded by a small corona of dystrophic neurites, which are well known and have been frequently described in the literature. The temporal and entorhinal cortex was excluded from the analysis because this area shows a tau pathology that emerges independently from $A \beta$ or prion protein pathology, and is likely to represent an independent pathogenic process, which may explain the findings of Ishizawa et al. [52]. It is possible, but difficult to prove whether phosphorylation of tau in this area may be enhanced by the deposition of prion protein.

Those forms of prion diseases, which show labelling of perineuronal networks and small plaques [87], show tau rods in the vicinity of the perineuronal nets and around small plaques. In our series, microplaques in sCJD (Fig. 4d) as well as inherited forms with prominent plaques (Fig. 5) showed an obvious accumulation of tau at a higher density (Fig. 6e-h) forming short processes resembling dystrophic neurites. However, these intraplaque and periplaque neurites were still more granular than those associated with $A \beta$ plaques. Importantly, this phenomenon was observed in the absence of any $A \beta$ pathology. The most straightforward explanation of PrP-associated tau phosphorylation is a simple dose-dependent direct toxicity whereby PrP amyloid is directly involved in the process. Alternatively, a critical level of toxic species may be produced during the conversion process, which is thought to involve a number of conformational intermediates or side products during prion conversion and propagation, variably named as $\operatorname{PrP}^{*}$ [1] or $\operatorname{PrP}^{\mathrm{L}}$ (lethal) [24]. These toxic (by-) products, may directly or indirectly trigger pathways mentioned above and hence contribute to tau phosphorylation. However, considering the kinetics of abnormal protein accumulation in prion diseases [24], and the relative abundance of prion amyloid in comparison to hyperphosphorylated tau, makes the latter a likely side effect rather than a main trigger of prion neuropathogenesis. However, the dissection of the events involved in tau phosphorylation may well be the key to understand prion neurotoxicity. 
Table 2 Summary of all cases analysed in this study
All PrP, tau and $\mathrm{A} \beta$ scores were obtained using the scoring scheme shown in Figs. 1, 2, and 3. In case of multiple concurrent PrP patterns, the highest individual score (e.g. granular score 2 and synaptic score 1 = final score 2) was used. No cases with cerebellar $\mathrm{A} \beta$ were included in this study. A score 4 for frontal cortex tau was given in cases that clearly exceeded the intensity shown in Fig. 3. One case (sCJD VV) scored 0 for tau and was omitted. All other cases had a tau score of 1 or greater. Cases with a tau score of 4 (exceeding the density shown in Fig. 3) are also shown SCJD MM, MV, $V V$ sporadic CJD with PRNP codon 129 genotype,

$I P D$ inherited prion disease

\begin{tabular}{|c|c|c|c|c|c|c|c|c|c|c|c|}
\hline \multicolumn{12}{|c|}{ Cases included in the study } \\
\hline & \multicolumn{2}{|c|}{ MM } & \multicolumn{3}{|c|}{ MV } & \multicolumn{2}{|c|}{ VV } & \multicolumn{3}{|c|}{ NA } & $\Sigma$ \\
\hline SCJD & \multicolumn{2}{|c|}{31} & \multicolumn{3}{|c|}{10} & \multicolumn{2}{|c|}{12} & \multicolumn{3}{|c|}{5} & 58 \\
\hline IPD & \multicolumn{2}{|r|}{8} & \multicolumn{3}{|c|}{5} & \multicolumn{2}{|r|}{1} & \multicolumn{3}{|c|}{2} & 16 \\
\hline vCJD & \multicolumn{2}{|r|}{5} & \multicolumn{3}{|c|}{0} & \multicolumn{2}{|r|}{0} & \multicolumn{3}{|c|}{0} & 5 \\
\hline$\Sigma$ & \multicolumn{2}{|c|}{44} & \multicolumn{3}{|c|}{15} & \multicolumn{2}{|c|}{13} & \multicolumn{3}{|c|}{7} & 79 \\
\hline \multicolumn{12}{|c|}{ PrP deposition in the frontal cortex } \\
\hline & \multicolumn{3}{|c|}{ No $A \beta$} & \multicolumn{3}{|c|}{\begin{tabular}{|l|} 
Very mild \\
Diffuse $A \beta$ (A1)
\end{tabular}} & \multicolumn{3}{|c|}{$\begin{array}{l}\text { Moderate } \\
\text { diffuse } A \beta(A 2) \\
\text { and or Plaques } \\
\text { (P1-3) }\end{array}$} & & \\
\hline score & 1 & 2 & 3 & 1 & 2 & 3 & 1 & 2 & 3 & & \\
\hline sCJD MM & 3 & 8 & 4 & 1 & 1 & 0 & 2 & 6 & 4 & & 29 \\
\hline sCJD MV & 1 & 1 & 0 & 0 & 2 & 0 & 2 & 4 & 0 & & 10 \\
\hline sCJD VV & 0 & 2 & 1 & 2 & 2 & 0 & 1 & 2 & 2 & & 12 \\
\hline SCJD ND & 1 & 1 & 1 & 0 & 1 & 0 & 0 & 0 & 1 & & 5 \\
\hline IPD & 2 & 1 & 6 & 1 & 1 & 1 & 0 & 0 & 3 & & 15 \\
\hline vCJD & 0 & 1 & 3 & 0 & 1 & 0 & 0 & 0 & 0 & & 5 \\
\hline$\Sigma$ & 7 & 14 & 15 & 4 & 8 & 1 & 5 & 12 & 10 & & 76 \\
\hline Tau depositio & in $t$ & e fro & al cc & rtex & & & & & & & \\
\hline & No & & & $\begin{array}{l}\text { Ver } \\
\text { Diff } \\
\text { (A1) }\end{array}$ & $\begin{array}{l}\text { nilc } \\
\text { e } A\end{array}$ & & $\begin{array}{l}\text { Mor } \\
\text { diffu } \\
\text { and } \\
\text { (P1- }\end{array}$ & $\begin{array}{l}\text { erate } \\
\text { e } A \beta \\
\text { or PI }\end{array}$ & $\begin{array}{l}\text { or se } \\
\text { (A2, } \\
\text { que }\end{array}$ & & \\
\hline score & 1 & 2 & 3 & 1 & 2 & 3 & 1 & 2 & 3 & 4 & \\
\hline SCJD MM & 4 & 9 & 1 & 1 & 1 & 0 & 2 & 6 & 3 & 1 & 28 \\
\hline sCJD MV & 0 & 2 & 0 & 2 & 0 & 0 & 1 & 3 & 1 & 1 & 10 \\
\hline sCJD VV & 0 & 2 & 1 & 0 & 2 & 1 & 1 & 3 & 1 & 0 & 11 \\
\hline SCJD ND & 0 & 3 & 0 & 0 & 0 & 1 & 0 & 1 & 0 & 0 & 5 \\
\hline IPD & 1 & 2 & 5 & 0 & 1 & 1 & 0 & 2 & 1 & 0 & 13 \\
\hline $\mathrm{VCJD}$ & 0 & 0 & 4 & 0 & 0 & 1 & 0 & 0 & 0 & 0 & 5 \\
\hline$\Sigma$ & 5 & 18 & 11 & 3 & 4 & 4 & 4 & 15 & 6 & 2 & 72 \\
\hline Tau depositio & in $t$ & e cer & sellu & & & & & & & & \\
\hline & & & & & & & & & & & \\
\hline score & 0 & 1 & 2 & 3 & & & & & & & \\
\hline SCJD MM & 1 & 15 & 9 & 0 & & & & & & & 25 \\
\hline sCJD MV & 0 & 5 & 4 & 0 & & & & & & & 9 \\
\hline sCJD VV & 0 & 1 & 8 & 2 & & & & & & & 11 \\
\hline SCID ND & 0 & 1 & 3 & 0 & & & & & & & 4 \\
\hline IPD & 3 & 5 & 4 & 0 & & & & & & & 12 \\
\hline vCJD & 0 & 0 & 0 & 5 & & & & & & & 5 \\
\hline$\Sigma$ & 4 & 27 & 28 & 7 & & & & & & & 66 \\
\hline
\end{tabular}

\section{Phosphorylation of tau in the cerebellum: an underestimated feature?}

In our series of sporadic, inherited and variant forms of prion diseases, we detected formation of rod-shaped tau deposits in the molecular and granular layers. Some forms of sporadic prion diseases form abundant small plaques, alongside with synaptic PrP, which is associated with marked periplaque hyperphosphorylation of tau. The same observation is made in inherited prion disease with the predominant formation of cerebellar plaques, such as P102L GSS, where tau is associated with, but not limited to, plaques. We show here that sporadic forms trigger tau phosphorylation in the cerebellum in a "load-dependent" 
Table 3 Statistical analysis of relationship between prion protein deposition, tau phosphorylation and disease duration

\begin{tabular}{|c|c|c|c|c|}
\hline Parameter 1 & Parameter 2 & Number of cases & $R$ & Significance level \\
\hline Tau (frontal cortex), no $A \beta$ amyloid & $\begin{array}{l}\text { PrP deposits: the strongest score } \\
\text { was taken into account }\end{array}$ & 28 & 0.69 & $<0.01$ \\
\hline Tau (frontal cortex), no $A \beta$ amyloid & Duration of illness & 28 & -0.037 & n.s. \\
\hline Tau (cerebellum), all prion diseases) & PrP deposits & 69 & 0.50 & $<0.01$ \\
\hline Tau (cerebellum), all prion diseases & Duration of illness & 63 & 0.063 & n.s. \\
\hline Tau (cerebellum), sCJD only & PrP deposits & 52 & 0.39 & $<0.01$ \\
\hline Tau (cerebellum), sCJD only & Duration of illness & 49 & -0.16 & n.s. \\
\hline
\end{tabular}

Parameters 1 and 2 were correlated in Pearson's test (n.s. not significant)

\section{Phosphorylated tau in the cortex (inherited prion diseases)}

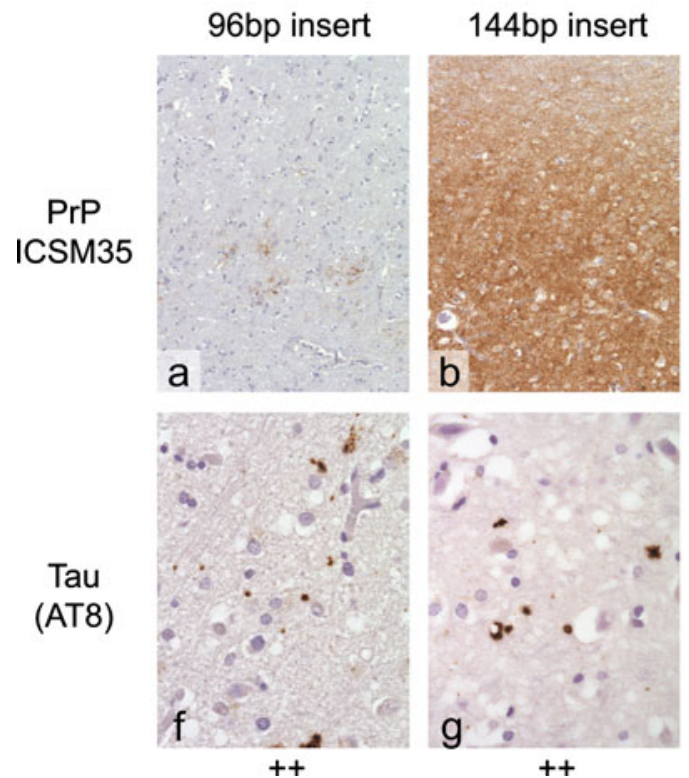

Fig. 5 PrP-induced tau phosphorylation in cortex of inherited prion diseases: upper row deposition of abnormal PrP in the frontal cortex; there is considerable variability of the intensity of $\operatorname{PrP}^{\mathrm{Sc}}$ burden and some forms are characterised by distinct patterns of plaque formation, as described before. The lower row shows tau deposits corresponding to the area depicted above. A, 96 bp OPRI mutation with almost undetectable $\mathrm{PrP}^{\mathrm{Sc}}$ load, resulting in tau phosphorylation similar to

fashion (Fig. 4; Table 3), where cases with a relatively low cerebellar burden of abnormal PrP show fewer rod-shaped tau positive inclusions (Fig. 4a, f) than those with an intermediate (Fig. 4b, g) or high PrP load (Fig. 4c, h). This correlation is statistically significant for SCJD (correlation coefficient $r=0.39, p<0.01$ ) which increases when all forms of prion diseases are included $(r=0.50 p<0.01)$. Tau phosphorylation in the cerebellum occurs in the molecular layer (Fig. 4f), granular layer (Fig. 4g) and in the Bergmann glia/Purkinje cell layer (Fig. 4h, i). vCJD is characterised by a particularly heavy deposition of abnormal PrP in the neocortex and the cerebellum (Fig. 4e), again there is a significant and dense deposition of hyperphosphorylated tau in all areas (Fig. 4j, molecular layer).
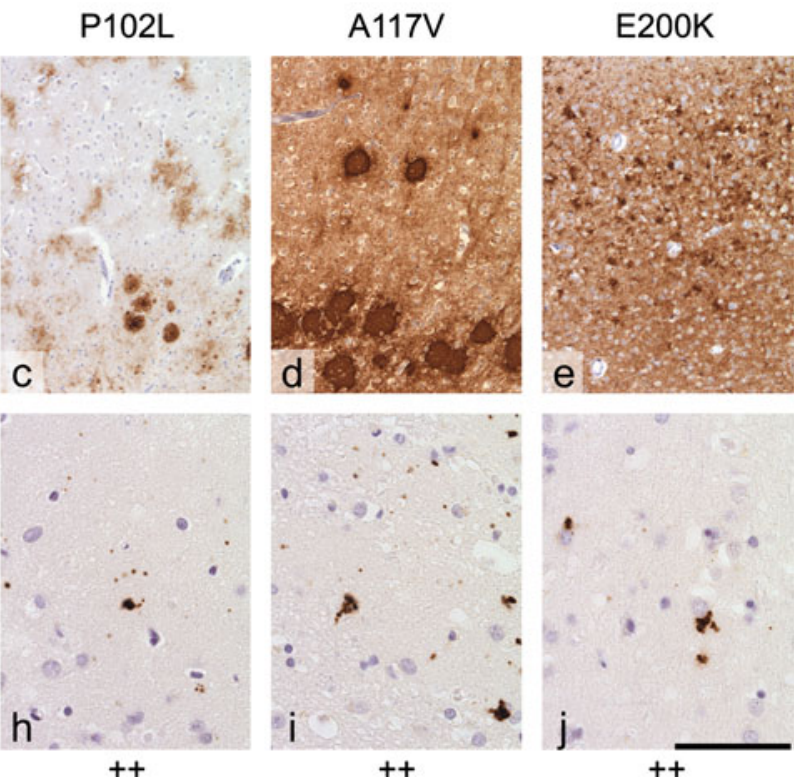

the 144 bp OPRI (f, g), despite its significantly higher $\operatorname{PrP}^{\mathrm{Sc}}$ load (b). c This case with a P102L mutation shows predominantly diffuse deposits and only very few plaques, as compared to the very heavily plaque-forming A117V case (d), both showing similar tau hyperphosphorylation (h, i). Another case with no plaque formation, E200K (e), shows a tau load similar to all other cases (j). Scale bar a-e $240 \mu \mathrm{m}, \mathbf{f}-\mathbf{j} 60 \mu \mathrm{m}$

Fig. 6 PrP deposits are congruent with hyperphosphorylated tau rods. Left column (heat maps) (a, e); $\mathbf{i}, \mathbf{m}$ numbers of tau rods or granules were determined per high power field on a section in the cortex and a small strip of adjacent subcortical white matter (immunostaining for AT8 Tau). Each field shows the count and a colour coded representation, (heat map). Middle column $\mathbf{b}, \mathbf{f}, \mathbf{j}, \mathbf{n}$ a parallel tissue section, stained for abnormal PrP shows deposits corresponding to the tau heat map. Right column $\mathbf{c}, \mathbf{d}, \mathbf{g}, \mathbf{h}, \mathbf{k}, \mathbf{l}, \mathbf{o}, \mathbf{p}$ high power magnification of the areas indicated by a blue square in the heat map and in the overview of the PrP labelled section (corresponding to ca $25 \%$ of the blue square). Arrows in the tau labelled section indicate very small granules $(\mathbf{d}, \mathbf{l})$ : c perineuronal net pattern of abnormal PrP, no plaque formation and moderate density of tau particles (d), g more intense PrP deposition and formation of small plaques, which elicit heavier tau deposition (h). The homogenous synaptic deposit (j) corresponds to a homogenous distribution of tau, which appears in very small granules (i). The coarse granular PrP deposits $(\mathbf{n}, \mathbf{o})$ are associated with larger, better discernible tau granule (p). Scale bar $\mathbf{b}, \mathbf{f}, \mathbf{i} 1,500 \mu \mathrm{m}, \mathbf{c}, \mathbf{d}, \mathbf{g}, \mathbf{h}, \mathbf{k}, \mathbf{l} 140 \mu \mathrm{m}$ 
When comparing the cerebellar tau in brains with 96 bp OPRI, 144 bp OPRI, P102L, A117V and E200K mutations (Fig. 4k-t), we found that (1) plaque and synaptic PrP elicit a similar degree of tau hyperphosphorylation, but (2) varies between genotypes, which is particularly evident when comparing with 96 and $144 \mathrm{bp}$ OPRI (Fig. 4s, t).

These findings can be interpreted as follows: (1) within one type of PrP (e.g. sCJD prion protein) the degree of tau phosphorylation is likely to be dose (or load-) dependent,

\section{Tau phosphorylation corresponds to PrP deposits}

Cortical

layer Tau positive inclusions (counts per HPF)

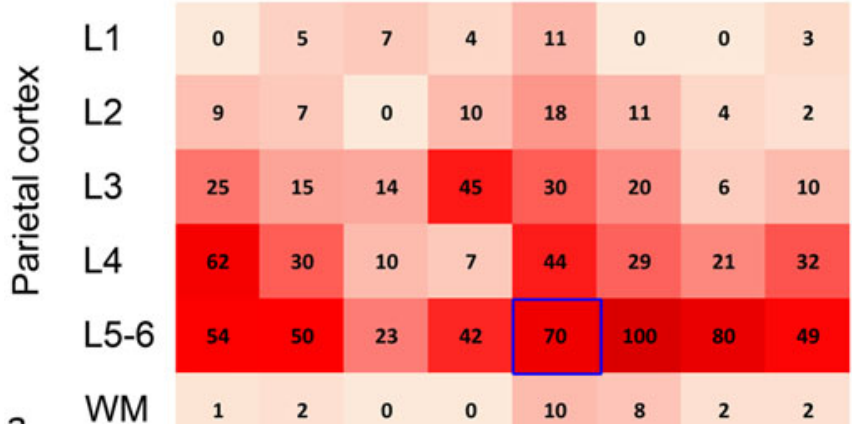

a
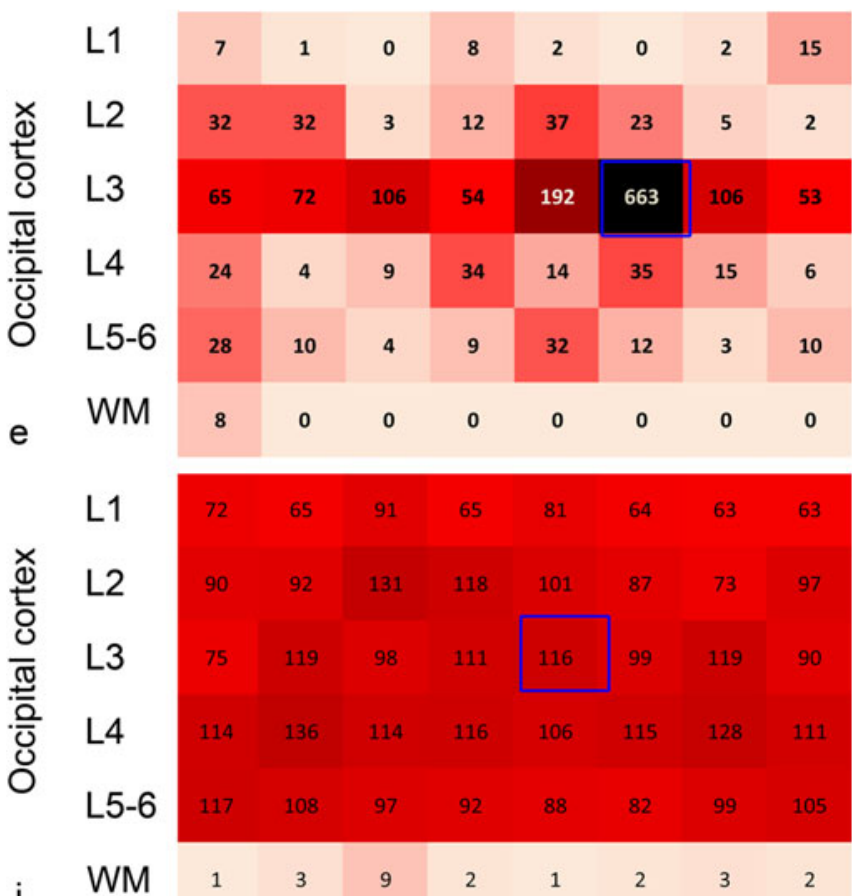

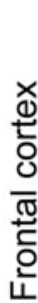

$\mathrm{m}$

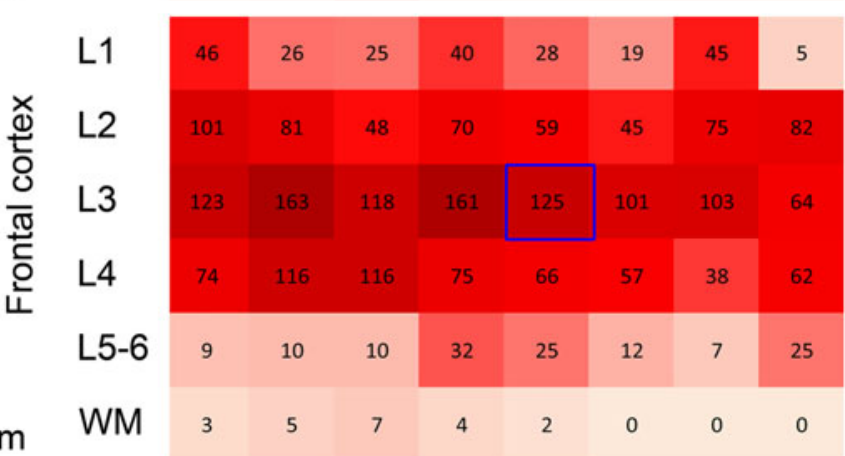

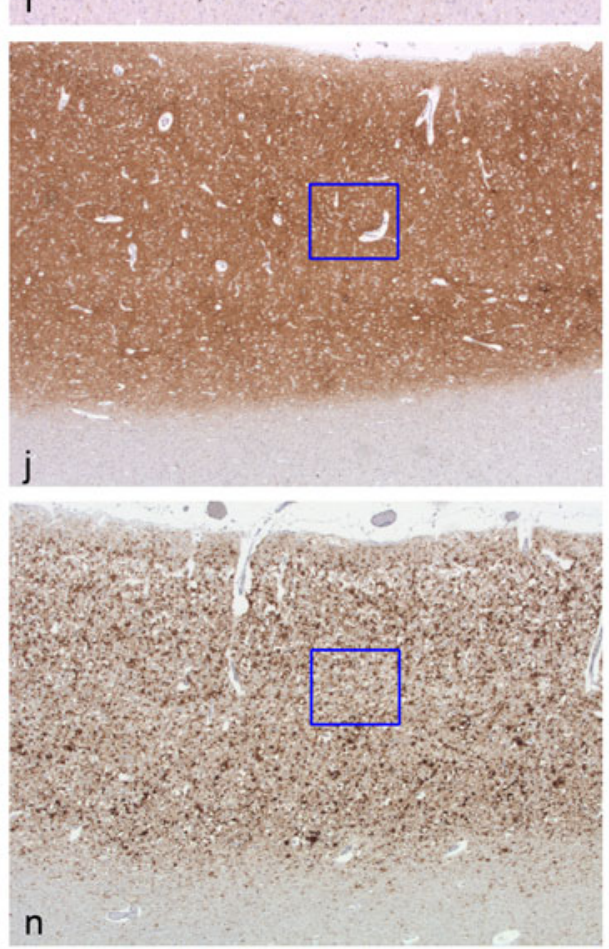

Detail

Corresponding PrP deposition

PrP and Tau
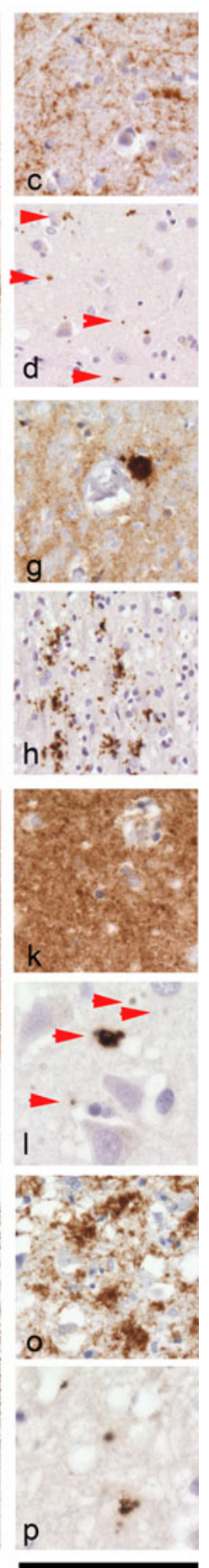
as shown in Fig. 4a-c and $\mathrm{f}-\mathrm{h}$; whilst (2) each genetic mutation is able to elicit a response that is specific to a given mutation, suggesting that the PrP load and tau phosphorylation may not be comparable between different mutations (Fig. $4 \mathrm{p}-\mathrm{t}$ ). The relatively small number of inherited forms investigated here does not allow for robust statistical analysis. It has been argued that the long duration may contribute to the extent of tau phosphorylation, as vCJD and GSS show significantly higher tau load and have longer incubation times than SCJD. We show here that there is no correlation between the duration of the illness and the degree of tau phosphorylation. Prion protein load appears to be the main factor triggering tau phosphorylation.

The capacity of cerebellar neurons to hyperphosphorylate tau has only recently been recognised and is probably generally underestimated. Primary tauopathies, such as progressive supranuclear palsy (PSP) are examples of the capacity of cerebellar Purkinje cells $[55,80]$ or neurones of the dentate gyrus [93] to hyperphosphorylate tau. In patients with PSP or corticobasal degeneration, the clinical phenotype of cerebellar ataxia is directly associated with the progressive accumulation of hyperphosphorylated tau in Purkinje cells [55]. Another disease featuring tau phosphorylation in cerebellar neurones is Niemann-Pick disease where defects in the intracellular trafficking of exogenous cholesterol causes neurodegeneration. Neurofibrillary tangles in the cortex of Niemann-Pick brains are morphologically similar to those in $\mathrm{AD}$. In the cerebellum, there is a marked deposition of phospho-tau in the dentate nucleus and granular layers of the cerebellum [66], but a remarkable absence of neurofibrillary tangles (NFT) is noted [17]. Several mouse models have addressed this [18] and whilst accumulation of hyperphosphorylated tau in cerebellar granule or Purkinje neurones can be successfully achieved in several mouse models (stress-induced [76], Niemann-Pick disease type C [18], pAkt-mediated tau phosphorylation [71]), no model has yet achieved formation of NFT, highlighting a specific pathway or cellular machinery required for NFT formation that is absent in the cerebellum [18]. A transgenic mouse expressing human P301L mutant tau did not show cerebellar tau at all [63].

One of the reasons that cerebellar tau phosphorylation is widely underestimated is the presence of abundant cortical phospho-tau in the neocortex in Alzheimer's disease whilst it is strikingly absent from the cerebellum, due to the lack of significant $A \beta$ accumulation in the cerebellum. If at all, $\mathrm{A} \beta$ deposits in the cerebellum only at late stages of the disease process. Only few studies have demonstrated $A \beta$ deposition in the cerebellum [4] forming diffuse deposits, but no plaques with dystrophic neurites [58]. Cases of familial $A D$ can show a significant $A \beta$ burden in the cerebellum, and can form deposits of various shapes and sizes
[32]. In the same series, cases with sporadic AD showed diffuse and granular deposits, and may, therefore, have represented a group with high overall A $\beta$ load [4]. More commonly, vascular $A \beta$ may cause cerebellar haemorrhages [26] or infarctions [19]. Familial AD cerebella accumulate mutant $\mathrm{A} \beta 42$ [54, 72], whilst in sporadic $\mathrm{AD}$, these deposits are composed of A 440 amyloid in humans [70] as well as in experimental models [48].

Most studies including recent multicenter studies of the neuropathology of AD have not systematically examined tau hyperphosphorylation in the cerebellum [2,3]. A recent biochemical and confocal imaging study has demonstrated co-localisation of tau and $A \beta$ in synaptosomes of all brain regions, including the cerebellar samples, which showed the lowest levels within the CNS [30].

In contrast to Alzheimer's disease where cerebellar $A \beta$ is essentially absent, most sporadic, inherited and transmitted forms (iatrogenic CJD, variant CJD and Kuru) of prion disease are characterised by a substantial prion protein deposition in the cerebellum (Fig. 4e). In SCJD, cerebellar prion protein is often seen as synaptic, homogenous deposit in the molecular layer and to a lesser extent, in the granular layer (Fig. 4a-d). Other typical patterns are characterised by small granular deposits, which may become confluent to form microplaques. Kuru, an acquired prion disease in humans, transmitted by oral uptake during mortuary feasts in the Fore linguistic group in Papua New Guinea, is clinically characterised by cerebellar ataxia, rather than dementia, and shows a marked involvement of the cerebellum, with formation of dense plaques of variable sizes [12, 43].

Iatrogenic prion disease can be caused by a wide variety of procedures, mostly due to the transmission of CJD prions contained in contaminated growth hormone derived from human cadavers, or by implantation of contaminated dura mater grafts [15, 39], transmission of CJD prions during corneal transplantation [28, 47], contaminated electroencephalographic (EEG) electrode implantation or surgical operations using contaminated instruments or apparatus [14]. The pattern of prion protein deposition is characterised by synaptic PrP and formation of small and medium sized plaques in neocortex and in the cerebellum.

Finally, vCJD in the UK and other countries, caused by human exposure to BSE prions from cattle (Collinge et al. 1996; Bruce et al. 1997; Hill et al. 1997; Collinge 1999; Asante et al. 2002), is characterised by extensive plaque formation including the cerebellum.

\section{Conclusion}

The capacity of disease-associated PrP to trigger phosphorylation of tau has been discovered sequentially. Early 
reports have described this phenomenon in obvious cases, where abundant plaques were present. Increasing awareness and understanding of this phenomenon and refinement of immunohistochemical and biochemical techniques have subsequently triggered additional studies, extending the observation to variant CJD and plaque-forming sporadic prion diseases. In parallel, the recognition of prionopathies and prion-like mechanisms as a concept for neurodegenerative disease pathogenesis has triggered a wealth of comparative experiments which led to the discovery of similarities and functional relationships between $A \beta$ and prion protein. Tau takes part in this process and we have highlighted the evidence that may represent a mechanism of amyloid toxicity. Although the relationship between amyloid toxicity and tau phosphorylation appears straightforward in our cohort of SCJD cases, the issue may be more complicated in inherited prion diseases. Other parameters that were not systematically addressed in our study are genetic (tau haplotype, PRNP codon 129 genotype) or demographic factors (e.g. age of onset). Our data presented here underpin the concept of amyloid-triggered tau phosphorylation, further contribute to the understanding of the relationship between prion amyloid and tau toxicity and set the scene for future research on larger cohorts. Furthering the study of pathways involved in tau phosphorylation may also be the key to understand prion neurotoxicity.

Open Access This article is distributed under the terms of the Creative Commons Attribution Noncommercial License which permits any noncommercial use, distribution, and reproduction in any medium, provided the original author(s) and source are credited.

\section{References}

1. Aguzzi A, Weissmann C (1997) Prion research: the next frontiers. Nature 389:795-798

2. Alafuzoff I, Arzberger T, Al-Sarraj S, Bodi I, Bogdanovic N, Braak H, Bugiani O, Del-Tredici K, Ferrer I, Gelpi E, Giaccone G, Graeber MB, Ince P, Kamphorst W, King A, Korkolopoulou P, Kovacs GG, Larionov S, Meyronet D, Monoranu C, Parchi P, Patsouris E, Roggendorf W, Seilhean D, Tagliavini F, Stadelmann C, Streichenberger N, Thal DR, Wharton SB, Kretzschmar H (2008) Staging of neurofibrillary pathology in Alzheimer's disease: a study of the BrainNet Europe Consortium. Brain Pathol $18: 484-496$

3. Alafuzoff I, Pikkarainen M, Al-Sarraj S, Arzberger T, Bell J, Bodi I, Bogdanovic N, Budka H, Bugiani O, Ferrer I, Gelpi E, Giaccone G, Graeber MB, Hauw JJ, Kamphorst W, King A, Kopp N, Korkolopoulou P, Kovacs GG, Meyronet D, Parchi P, Patsouris E, Preusser M, Ravid R, Roggendorf W, Seilhean D, Streichenberger N, Thal DR, Kretzschmar H (2006) Interlaboratory comparison of assessments of Alzheimer disease-related lesions: a study of the BrainNet Europe Consortium. J Neuropathol Exp Neurol 65:740-757

4. Alafuzoff I, Thal DR, Arzberger T, Bogdanovic N, Al-Sarraj S, Bodi I, Boluda S, Bugiani O, Duyckaerts C, Gelpi E, Gentleman
S, Giaccone G, Graeber M, Hortobagyi T, Hoftberger R, Ince P, Ironside JW, Kavantzas N, King A, Korkolopoulou P, Kovacs GG, Meyronet D, Monoranu C, Nilsson T, Parchi P, Patsouris E, Pikkarainen M, Revesz T, Rozemuller A, Seilhean D, SchulzSchaeffer W, Streichenberger N, Wharton SB, Kretzschmar H (2009) Assessment of beta-amyloid deposits in human brain: a study of the BrainNet Europe Consortium. Acta Neuropathol 117:309-320

5. Amano N, Yagishita S, Yokoi S, Itoh Y, Kinoshita J, Mizutani T, Matsuishi T (1992) Gerstmann-Straussler syndrome-a variant type: amyloid plaques and Alzheimer's neurofibrillary tangles in cerebral cortex. Acta Neuropathol Berl 84:15-23

6. Asante EA, Linehan JM, Desbruslais M, Joiner S, Gowland I, Wood AL, Welch J, Hill AF, Lloyd SE, Wadsworth JD, Collinge J (2002) BSE prions propagate as either variant CJD-like or sporadic CJD-like prion strains in transgenic mice expressing human prion protein. EMBO J 21:6358-6366

7. Bitan G, Fradinger EA, Spring SM, Teplow DB (2005) Neurotoxic protein oligomers-what you see is not always what you get. Amyloid 12:88-95

8. Boellaard JW, Doerr Schott J, Schlote W (1993) Miniplaques and shapeless cerebral amyloid deposits in a case of GerstmannStraussler-Scheinker's syndrome. Acta Neuropathol Berl 86: 532-535

9. Bolmont T, Clavaguera F, Meyer-Luehmann M, Herzig MC, Radde R, Staufenbiel M, Lewis J, Hutton M, Tolnay M, Jucker M (2007) Induction of tau pathology by intracerebral infusion of amyloid-beta-containing brain extract and by amyloid-beta deposition in APP $\times$ Tau transgenic mice. Am J Pathol 171: 2012-2020

10. Braak H, Braak E (1995) Staging of Alzheimer's disease-related neurofibrillary changes. Neurobiol Aging 16:271-278 (discussion 278-284)

11. Braak H, Braak E, Bohl J (1993) Staging of Alzheimer-related cortical destruction. Eur Neurol 33:403-408

12. Brandner S, Whitfield J, Boone K, Puwa A, O'Malley C, Linehan JM, Joiner S, Scaravilli F, Calder I, PA M, Wadsworth JD, Collinge J (2008) Central and peripheral pathology of kuru: pathological analysis of a recent case and comparison with other forms of human prion disease. Philos Trans R Soc Lond B Biol Sci 363:3755-3763

13. Brown DR (2000) Altered toxicity of the prion protein peptide PrP106-126 carrying the Ala(117) $>$ Val mutation. Biochem J 346(Pt 3):785-791

14. Brown P, Preece M, Brandel JP, Sato T, McShane L, Zerr I, Fletcher A, Will RG, Pocchiari M, Cashman NR, d'Aignaux JH, Cervenakova L, Fradkin J, Schonberger LB, Collins SJ (2000) Iatrogenic Creutzfeldt-Jakob disease at the millennium. Neurology 55:1075-1081

15. Brown P, Preece MA, Will RG (1992) "Friendly fire" in medicine: hormones, homografts, and Creutzfeldt-Jakob disease. Lancet 340:24-27

16. Bruce ME, Will RG, Ironside JW, McConnell I, Drummond D, Suttie A, McCardle L, Chree A, Hope J, Birkett C, Cousens S, Fraser H, Bostock CJ (1997) Transmissions to mice indicate that 'new variant' CJD is caused by the BSE agent. Nature 389:498501

17. Bu B, Klunemann H, Suzuki K, Li J, Bird T, Jin LW, Vincent I (2002) Niemann-Pick disease type $C$ yields possible clue for why cerebellar neurons do not form neurofibrillary tangles. Neurobiol Dis 11:285-297

18. Bu B, Li J, Davies P, Vincent I (2002) Deregulation of cdk5, hyperphosphorylation, and cytoskeletal pathology in the Niemann-Pick type C murine model. J Neurosci 22:6515-6525

19. Cadavid D, Mena H, Koeller K, Frommelt RA (2000) Cerebral beta amyloid angiopathy is a risk factor for cerebral ischemic 
infarction: a case control study in human brain biopsies. J Neuropathol Exp Neurol 59:768-773

20. Camins A, Verdaguer E, Folch J, Canudas AM, Pallas M (2006) The role of CDK5/P25 formation/inhibition in neurodegeneration. Drug News Perspect 19:453-460

21. Campbell TA, Palmer MS, Will RG, Gibb WR, Luthert PJ, Collinge J (1996) A prion disease with a novel 96-base pair insertional mutation in the prion protein gene. Neurology 46:761-766

22. Capellari S, Vital C, Parchi P, Petersen RB, Ferrer X, Jarnier D, Pegoraro E, Gambetti P, Julien J (1997) Familial prion disease with a novel 144-bp insertion in the prion protein gene in a Basque family. Neurology 49:133-141

23. Clavaguera F, Bolmont T, Crowther RA, Abramowski D, Frank S, Probst A, Fraser G, Stalder AK, Beibel M, Staufenbiel M, Jucker M, Goedert M, Tolnay M (2009) Transmission and spreading of tauopathy in transgenic mouse brain. Nat Cell Biol 11:909-913

24. Collinge J, Clarke AR (2007) A general model of prion strains and their pathogenicity. Science 318:930-936

25. Collinge J, Sidle KC, Meads J, Ironside J, Hill AF (1996) Molecular analysis of prion strain variation and the aetiology of 'new variant' CJD. Nature 383:685-690

26. Cuny E, Loiseau H, Rivel J, Vital C, Castel JP (1996) Amyloid angiopathy-related cerebellar hemorrhage. Surg Neurol 46: 235-239

27. Duchen LW, Poulter M, Harding AE (1993) Dementia associated with a 216 base pair insertion in the prion protein gene. Clinical and neuropathological features. Brain 116:555-567

28. Duffy P, Wolf J, Collins G, DeVoe AG, Streeten B, Cowen D (1974) Possible person-to-person transmission of CreutzfeldtJakob disease. N Engl J Med 290:692-693

29. Eisele YS, Bolmont T, Heikenwalder M, Langer F, Jacobson LH, Yan ZX, Roth K, Aguzzi A, Staufenbiel M, Walker LC, Jucker M (2009) Induction of cerebral beta-amyloidosis: intracerebral versus systemic Abeta inoculation. Proc Natl Acad Sci USA 106:12926-12931

30. Fein JA, Sokolow S, Miller CA, Vinters HV, Yang F, Cole GM, Gylys KH (2008) Co-localization of amyloid beta and tau pathology in Alzheimer's disease synaptosomes. Am J Pathol 172:1683-1692

31. Ferrer I, Santpere G, van Leeuwen FW (2008) Argyrophilic grain disease. Brain 131:1416-1432

32. Fukutani Y, Cairns NJ, Rossor MN, Lantos PL (1997) Cerebellar pathology in sporadic and familial Alzheimer's disease including APP 717 (Val > Ile) mutation cases: a morphometric investigation. J Neurol Sci 149:177-184

33. Ghetti B, Piccardo P, Spillantini MG, Ichimiya Y, Porro M, Perini F, Kitamoto T, Tateishi J, Seiler C, Frangione B, Bugiani O, Giaccone G, Prelli F, Goedert M, Dlouhy SR, Tagliavini F (1996) Vascular variant of prion protein cerebral amyloidosis with tau-positive neurofibrillary tangles: the phenotype of the stop codon 145 mutation in PRNP. Proc Natl Acad Sci USA 93:744-748

34. Ghetti B, Tagliavini F, Giaccone G, Bugiani O, Frangione B, Farlow MR, Dlouhy SR (1994) Familial Gerstmann-StrausslerScheinker disease with neurofibrillary tangles. Mol Neurobiol 8:41-48

35. Ghetti B, Tagliavini F, Masters CL, Beyreuther K, Giaccone G, Verga L, Farlow MR, Conneally PM, Dlouhy SR, Azzarelli B et al (1989) Gerstmann-Straussler-Scheinker disease, II: Neurofibrillary tangles and plaques with PrP-amyloid coexist in an affected family. Neurology 39:1453-1461

36. Giaccone G, Mangieri M, Capobianco R, Limido L, Hauw JJ, Haik S, Fociani P, Bugiani O, Tagliavini F (2008) Tauopathy in human and experimental variant Creutzfeldt-Jakob disease. Neurobiol Aging 29:1864-1873
37. Glabe C (2001) Intracellular mechanisms of amyloid accumulation and pathogenesis in Alzheimer's disease. J Mol Neurosci $17: 137-145$

38. Gotz J, Chen F, van Dorpe J, Nitsch RM (2001) Formation of neurofibrillary tangles in P3011 tau transgenic mice induced by Abeta 42 fibrils. Science 293:1491-1495

39. Griffin JP (1991) Transmission of Creutzfeldt-Jakob disease by investigative and therapeutic procedures. Adverse Drug React Toxicol Rev 10:89-98

40. Griffith JS (1967) Self-replication and scrapie. Nature 215:10431044

41. Gunther EC, Strittmatter SM (2010) beta-Amyloid oligomers and cellular prion protein in Alzheimer's disease. J Mol Med 88:331338

42. Haass C, Selkoe DJ (2007) Soluble protein oligomers in neurodegeneration: lessons from the Alzheimer's amyloid betapeptide. Nat Rev Mol Cell Biol 8:101-112

43. Hainfellner JA, Parchi P, Kitamoto T, Jarius C, Gambetti P, Budka H (1999) A novel phenotype in familial Creutzfeldt-Jakob disease: prion protein gene E200K mutation coupled with valine at codon 129 and type 2 protease-resistant prion protein. Ann Neurol 45:812-816

44. Hardy JA, Higgins GA (1992) Alzheimer's disease: the amyloid cascade hypothesis. Science 256:184-185

45. Hernandez F, de Barreda EG, Fuster-Matanzo A, Goni-Oliver P, Lucas JJ, Avila J (2009) The role of GSK3 in Alzheimer disease. Brain Res Bull 80:248-250

46. Hernandez F, Gomez de Barreda E, Fuster-Matanzo A, Lucas JJ, Avila J (2009) GSK3: a possible link between beta amyloid peptide and tau protein. Exp Neurol. doi:10.1016/j.physletb. 2003.10.071

47. Herzberg L (1979) Creutzfeld-Jakob disease and corneal grafts. Med J Aust 1:248

48. Herzig MC, Winkler DT, Burgermeister P, Pfeifer M, Kohler E, Schmidt SD, Danner S, Abramowski D, Sturchler-Pierrat C, Burki K, van Duinen SG, Maat-Schieman ML, Staufenbiel M, Mathews PM, Jucker M (2004) Abeta is targeted to the vasculature in a mouse model of hereditary cerebral hemorrhage with amyloidosis. Nat Neurosci 7:954-960

49. Hill AF, Desbruslais M, Joiner S, Sidle KC, Gowland I, Collinge J, Doey LJ, Lantos P (1997) The same prion strain causes vCJD and BSE. Nature 389:448-450, 526

50. Holton JL, Ghiso J, Lashley T, Rostagno A, Guerin CJ, Gibb G, Houlden H, Ayling H, Martinian L, Anderton BH, Wood NW, Vidal R, Plant G, Frangione B, Revesz T (2001) Regional distribution of amyloid-Bri deposition and its association with neurofibrillary degeneration in familial British dementia. Am J Pathol 158:515-526

51. Hooper C, Killick R, Lovestone S (2008) The GSK3 hypothesis of Alzheimer's disease. J Neurochem 104:1433-1439

52. Ishizawa K, Komori T, Shimazu T, Yamamoto T, Kitamoto T, Shimazu K, Hirose T (2002) Hyperphosphorylated tau deposition parallels prion protein burden in a case of Gerstmann-StrausslerScheinker syndrome P102L mutation complicated with dementia. Acta Neuropathol 104:342-350

53. Itoh $Y$, Yamada $M$, Hayakawa $M$, Shozawa $T$, Tanaka J, Matsushita M, Kitamoto T, Tateishi J, Otomo E (1994) A variant of Gerstmann-Straussler-Scheinker disease carrying codon 105 mutation with codon 129 polymorphism of the prion protein gene: a clinicopathological study. J Neurol Sci 127:77-86

54. Kalaria RN, Cohen DL, Greenberg BD, Savage MJ, Bogdanovic NE, Winblad B, Lannfelt L, Adem A (1996) Abundance of the longer A beta 42 in neocortical and cerebrovascular amyloid beta deposits in Swedish familial Alzheimer's disease and Down's syndrome. Neuroreport 7:1377-1381 
55. Kanazawa M, Shimohata T, Toyoshima Y, Tada M, Kakita A, Morita T, Ozawa T, Takahashi H, Nishizawa M (2009) Cerebellar involvement in progressive supranuclear palsy: a clinicopathological study. Mov Disord 24:1312-1318

56. Kerr F, Rickle A, Nayeem N, Brandner S, Cowburn RF, Lovestone S (2006) PTEN, a negative regulator of PI3 kinase signalling, alters tau phosphorylation in cells by mechanisms independent of GSK-3. FEBS Lett 580:3121-3128

57. Krasnianski A, von Ahsen N, Heinemann U, Meissner B, Kretzschmar HA, Armstrong VW, Zerr I (2008) ApoE distribution and family history in genetic prion diseases in Germany. J Mol Neurosci 34:45-50

58. Larner AJ (1997) The cerebellum in Alzheimer's disease. Dement Geriatr Cogn Disord 8:203-209

59. Lauren J, Gimbel DA, Nygaard HB, Gilbert JW, Strittmatter SM (2009) Cellular prion protein mediates impairment of synaptic plasticity by amyloid-beta oligomers. Nature 457:1128-1132

60. Lebel M, Patenaude C, Allyson J, Massicotte G, Cyr M (2009) Dopamine D1 receptor activation induces tau phosphorylation via cdk5 and GSK3 signaling pathways. Neuropharmacology 57: 392-402

61. Lesne S, Koh MT, Kotilinek L, Kayed R, Glabe CG, Yang A, Gallagher M, Ashe KH (2006) A specific amyloid-beta protein assembly in the brain impairs memory. Nature 440:352-357

62. Lewis J, Dickson DW, Lin WL, Chisholm L, Corral A, Jones G, Yen SH, Sahara N, Skipper L, Yager D, Eckman C, Hardy J, Hutton M, McGowan E (2001) Enhanced neurofibrillary degeneration in transgenic mice expressing mutant tau and APP. Science 293:1487-1491

63. Lewis J, McGowan E, Rockwood J, Melrose H, Nacharaju P, Van Slegtenhorst M, Gwinn-Hardy K, Paul Murphy M, Baker M, Yu X, Duff K, Hardy J, Corral A, Lin WL, Yen SH, Dickson DW, Davies P, Hutton M (2000) Neurofibrillary tangles, amyotrophy and progressive motor disturbance in mice expressing mutant (P301L) tau protein. Nat Genet 25:402-405

64. Lopes JP, Oliveira CR, Agostinho P (2007) Role of cyclindependent kinase 5 in the neurodegenerative process triggered by amyloid-Beta and prion peptides: implications for Alzheimer's disease and prion-related encephalopathies. Cell Mol Neurobiol 27:943-957

65. Lopes JP, Oliveira CR, Agostinho P (2009) Cdk5 acts as a mediator of neuronal cell cycle re-entry triggered by amyloidbeta and prion peptides. Cell Cycle 8:97-104

66. Love S, Bridges LR, Case CP (1995) Neurofibrillary tangles in Niemann-Pick disease type C. Brain 118(Pt 1):119-129

67. Marino S, Krimpenfort P, Leung C, van der Korput HA, Trapman J, Camenisch I, Berns A, Brandner S (2002) PTEN is essential for cell migration but not for fate determination and tumourigenesis in the cerebellum. Development 129:3513-3522

68. Mead S, James-Galton M, Revesz T, Doshi RB, Harwood G, Pan EL, Ghiso J, Frangione B, Plant G (2000) Familial British dementia with amyloid angiopathy: early clinical, neuropsychological and imaging findings. Brain 123(Pt 5):975-991

69. Meyer-Luehmann M, Coomaraswamy J, Bolmont T, Kaeser S, Schaefer C, Kilger E, Neuenschwander A, Abramowski D, Frey P, Jaton AL, Vigouret JM, Paganetti P, Walsh DM, Mathews PM, Ghiso J, Staufenbiel M, Walker LC, Jucker M (2006) Exogenous induction of cerebral beta-amyloidogenesis is governed by agent and host. Science 313:1781-1784

70. Mori H, Takio K, Ogawara M, Selkoe DJ (1992) Mass spectrometry of purified amyloid beta protein in Alzheimer's disease. J Biol Chem 267:17082-17086

71. Nayeem N, Kerr F, Naumann H, Linehan J, Lovestone S, Brandner S (2007) Hyperphosphorylation of tau and neurofilaments and activation of CDK5 and ERK1/2 in PTEN-deficient cerebella. Mol Cell Neurosci 34:400-408
72. Nishitsuji K, Tomiyama T, Ishibashi K, Kametani F, Ozawa K, Okada R, Maat-Schieman ML, Roos RA, Iwai K, Mori H (2007) Cerebral vascular accumulation of Dutch-type Abeta42, but not wild-type Abeta42, in hereditary cerebral hemorrhage with amyloidosis, Dutch type. J Neurosci Res 85:2917-2923

73. Nochlin D, Sumi SM, Bird TD, Snow AD, Leventhal CM, Beyreuther K, Masters CL (1989) Familial dementia with PrPpositive amyloid plaques: a variant of Gerstmann-Straussler syndrome. Neurology 39:910-918

74. Nygaard HB, Strittmatter SM (2009) Cellular prion protein mediates the toxicity of beta-amyloid oligomers: implications for Alzheimer disease. Arch Neurol 66:1325-1328

75. Oddo S, Billings L, Kesslak JP, Cribbs DH, LaFerla FM (2004) Abeta immunotherapy leads to clearance of early, but not late, hyperphosphorylated tau aggregates via the proteasome. Neuron 43:321-332

76. Okawa Y, Ishiguro K, Fujita SC (2003) Stress-induced hyperphosphorylation of tau in the mouse brain. FEBS Lett 535:183-189

77. Parkin ET, Watt NT, Hussain I, Eckman EA, Eckman CB, Manson JC, Baybutt HN, Turner AJ, Hooper NM (2007) Cellular prion protein regulates beta-secretase cleavage of the Alzheimer's amyloid precursor protein. Proc Natl Acad Sci USA 104:11062-11067

78. Patrick GN, Zukerberg L, Nikolic M, de la Monte S, Dikkes P, Tsai LH (1999) Conversion of p35 to p25 deregulates Cdk5 activity and promotes neurodegeneration. Nature 402:615-622

79. Perez M, Rojo AI, Wandosell F, Diaz-Nido J, Avila J (2003) Prion peptide induces neuronal cell death through a pathway involving glycogen synthase kinase 3. Biochem J 372:129-136

80. Piao YS, Hayashi S, Wakabayashi K, Kakita A, Aida I, Yamada M, Takahashi H (2002) Cerebellar cortical tau pathology in progressive supranuclear palsy and corticobasal degeneration. Acta Neuropathol 103:469-474

81. Pimplikar SW (2009) Reassessing the amyloid cascade hypothesis of Alzheimer's disease. Int J Biochem Cell Biol 41:1261-1268

82. Plant GT, Revesz T, Barnard RO, Harding AE, Gautier-Smith PC (1990) Familial cerebral amyloid angiopathy with nonneuritic amyloid plaque formation. Brain 113(Pt 3):721-747

83. Prusiner SB (1982) Novel proteinaceous infectious particles cause scrapie. Science 216:136-144

84. Puri R, Suzuki T, Yamakawa K, Ganesh S (2009) Hyperphosphorylation and aggregation of Tau in laforin-deficient mice, an animal model for Lafora disease. J Biol Chem 284:22657-22663

85. Revesz T, Holton JL, Doshi B, Anderton BH, Scaravilli F, Plant GT (1999) Cytoskeletal pathology in familial cerebral amyloid angiopathy (British type) with non-neuritic amyloid plaque formation. Acta Neuropathol 97:170-176

86. Shankar GM, Li S, Mehta TH, Garcia-Munoz A, Shepardson NE, Smith I, Brett FM, Farrell MA, Rowan MJ, Lemere CA, Regan CM, Walsh DM, Sabatini BL, Selkoe DJ (2008) Amyloid-beta protein dimers isolated directly from Alzheimer's brains impair synaptic plasticity and memory. Nat Med 14:837-842

87. Sikorska B, Liberski PP, Sobow T, Budka H, Ironside JW (2009) Ultrastructural study of florid plaques in variant CreutzfeldtJakob disease: a comparison with amyloid plaques in kuru, sporadic Creutzfeldt-Jakob disease and Gerstmann-StrausslerScheinker disease. Neuropathol Appl Neurobiol 35:46-59

88. Sobue K, Agarwal-Mawal A, Li W, Sun W, Miura Y, Paudel HK (2000) Interaction of neuronal Cdc2-like protein kinase with microtubule-associated protein tau. J Biol Chem 275:1667316680

89. Tagliavini F, Prelli F, Ghiso J, Bugiani O, Serban D, Prusiner SB, Farlow MR, Ghetti B, Frangione B (1991) Amyloid protein of Gerstmann-Straussler-Scheinker disease (Indiana kindred) is an $11 \mathrm{kD}$ fragment of prion protein with an $\mathrm{N}$-terminal glycine at codon 58. EMBO J 10:513-519 
90. Townsend M, Shankar GM, Mehta T, Walsh DM, Selkoe DJ (2006) Effects of secreted oligomers of amyloid beta-protein on hippocampal synaptic plasticity: a potent role for trimers. J Physiol 572:477-492

91. Tranchant C, Doh Ura K, Steinmetz G, Chevalier Y, Kitamoto T, Tateishi J, Warter JM (1991) Mutation of codon 117 of the prion gene in Gerstmann-Straussler-Scheinker disease. Rev Neurol Paris 147:274-278

92. Webb TE, Poulter M, Beck J, Uphill J, Adamson G, Campbell T, Linehan J, Powell C, Brandner S, Pal S, Siddique D, Wadsworth JD, Joiner S, Alner K, Petersen C, Hampson S, Rhymes C, Treacy C, Storey E, Geschwind MD, Nemeth AH, Wroe S, Collinge J, Mead S (2008) Phenotypic heterogeneity and genetic modification of $\mathrm{P} 102 \mathrm{~L}$ inherited prion disease in an international series. Brain 131:2632-2646
93. Williams DR, Holton JL, Strand C, Pittman A, de Silva R, Lees AJ, Revesz T (2007) Pathological tau burden and distribution distinguishes progressive supranuclear palsy-parkinsonism from Richardson's syndrome. Brain 130:1566-1576

94. Worster-Drought C, MW Hill TR (1933) Familial presenile dementia with spastic paralysis. J Neurol Psychopathol 14:27-34

95. Yamada M, Itoh Y, Inaba A, Wada Y, Takashima M, Satoh S, Kamata T, Okeda R, Kayano T, Suematsu N, Kitamoto T, Otomo E, Matsushita M, Mizusawa H (1999) An inherited prion disease with a PrP P105L mutation: clinicopathologic and PrP heterogeneity (in process citation). Neurology 53:181-188

96. Zhang M, Li J, Chakrabarty P, Bu B, Vincent I (2004) Cyclindependent kinase inhibitors attenuate protein hyperphosphorylation, cytoskeletal lesion formation, and motor defects in NiemannPick type C mice. Am J Pathol 165:843-853 